\title{
Business Development Service: Addressing The Gap In The Western Cape, South Africa
}

\author{
Pradeep Brijlal, University of the Western Cape, South Africa
}

\begin{abstract}
A survey was conducted to evaluate utilization of business development services by small businesses in the Western Cape. It was deduced that fairly established businesses do not seem to need or use consultancy /training services. This may be due to the lack of awareness on the owner's part or perceived value of money. Emerging and stable businesses have a strong demand for financial support, business management advice and skills, market opportunities and technical skills. The new approach to business should entail identifying specific needs of business, considering its degree of sophistication and thereby providing services to meet those unmet needs
\end{abstract}

Keywords: Business development services; Western Cape; Business management; SMMEs.

\section{INTRODUCTION}

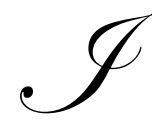

$\mathrm{t}$ is accepted worldwide that the development and growth of small, micro and medium enterprises (SMMEs) can play an important role in job creation, social stability and the economic welfare across the globe. It is for these reasons that the proliferation of small businesses in South Africa is beneficial and is welcome. Policies and programmes to support the development of SMMEs are therefore an important part of the democratic government's and non government organizations programmes to create a better life. Many African countries are reviewing their economic policies regarding the promotion of SMMEs.

Many SMMEs fail at the infancy stage and some fail a few years after start-up. It is estimated that 50 percent of all start-ups fail in their first year, and 75 percent fail within the first three to five years in the United States of America (Anderson and Dunkelberg 1990, cited in Ladzani and Van Vuuren, 2002). Data on small and medium enterprises in South Africa suggests that SMMEs contribute about half of total employment, more than $30 \%$ of total gross domestic product. Also, one out of five units exported is produced in the small and medium sector in South Africa. It is argued that management training should greatly improve SMME survival and performance (English, 2001).Despite stressing the importance of training to improve business performance, this area has received little attention in the literature. It would be of interest to policy makers and researcher in this field to determine the needs of SMMEs and identification of products and services that best suit those needs.

The International Finance Corporation IFC defines business development services as those non-financial services and products offered to entrepreneurs at various stages of their business needs. These services are primarily aimed at skills transfer or business advice. Business development services have traditionally been called nonfinancial services, and are sometimes offered in conjunction with credit and other financial services (Goldmark, 1996) Business development services are important because they can assist entrepreneurs to run their business more effectively and, if appropriately applied, can act as an enhancer of access to finance and as an alternative form of "collateral" in circumstances where tangible collateral may be an impediment to meeting traditional security requirements. (IFC, 2006).

According to the Committee of Donor Agencies for Small Enterprise Development of the ILO, the starting point for the design of any intervention intended to promote SMME development is an assessment of their needs and perceptions. Indeed, central to donor support for SMME development is the belief that their performance can be improved by changing the various factors affecting SMMEs. These include demand-side factors, such as 
geographical situation, consumer attitudes, purchasing power, politics and governance, as well as supply-side factors, including skills, networks, access to resources, infrastructure, the availability of information and government regulations and policies. Mintzberg (1989) states that barriers to SMME survival and growth are likely to be faced in all four functional areas of business operation - management, marketing, operations and finance - and may be directly related to the size and start-up conditions of the SMMEs.

Business Development Services (BDS) is primarily an activist function, seeking to both address market failure by providing information required by businesses, providing or facilitating the provision of consultancy services, providing or encouraging skills and business training; and improve equity by engaging in technology transfer and development, and providing subsidized access to infrastructure. In addition to the government provided training for SMMEs focusing on basic literacy, numeracy, and communication skills, Radipere and Scheers (2005) recommend that training should also focus on administration, financial management and marketing skills. Marketing as part of the business development service constitutes an important part of promoting SMMEs. Jackson (2004) argues that access to micro - credit is not the primary constraint to small enterprise development, but instead, there is an increasing shift towards the recognition of the critical importance of non-financial constraints such as the lack of information and the lack of management and business skills. It is through the delivery of business development services that these non-financial constraints can be addressed.

Essentially, there are two approaches to Business Development Services: traditional and market development approaches (Mcvay M et al, Gibson A, 2000). The failure of traditional approaches to business development (especially in relation to the achievement of scale, outreach and sustainability objectives) has in recent years led to a central paradigm shift in the approach to the provision of business support services in general, and business development services in particular. The success of emergent new micro-financing initiatives and the increasing realization that emerging businesses actually accesses many 'hidden' services from sources other than those specifically created to provide business development support (which, contrary to conventional wisdom is often purchased at full cost) has lent momentum to this shift. Succinctly, the emergent new paradigm places increasing emphasis in the delivery of business support services in general, and of business development services in particular, on the interplay of supply and demand in a functional marketplace. Intervention for BDS is temporary as it is directed for specific purpose of correcting/compensating for market imperfections and are scaled down and ultimately terminated as market channels develop. Emphasis shifts as new imperfections develop. Subsidization is now becoming a demand side instrument, a move from the traditional approach where it is seen as a supply side instrument (Mcvay and Gibson, 2000).

Caniëls, Romijn \& De Wildt (2003) strongly argue that the provision of business development services should be participatory. In the design of BDS programmes there should be a role for customers to co-determine innovation directions and priorities, act as partners in the actual design of new services, and to provide feedback. This paper examines the profile of the business and the services used or needed. The focus was on the micro and small businesses, as it is assumed that the failure rate seems to be higher in theses categories of business.

This paper provides useful insights about the utilization of business development services for a range of role players, including policymakers, academics, educational institutions and the public in general.

\section{OBJECTIVES}

The aim of the research was to investigate whether small and micro businesses used business development services and to identify the needs of small and micro enterprises and identify the products and services that best suit those needs. 


\section{RESEARCH METHODOLOGY}

\section{Sample Population}

One hundred and fifty small and micro size enterprises located within a 40km radius of Cape Town with turnover up to R6m (approximately 1.1 million USD) were randomly selected for the survey. The 150 small and micro enterprises were drawn from the Cape Metropolitan Council Financial Services Levy Database. 15000 Businesses were verified as 'live' - still operating in the Cape Town region and paying regular levies. By means of elimination - using the criteria area of operation, annual turnover and size - 1500 Businesses qualified for inclusion in the survey. 10 percent of the 1500 qualified businesses were considered representative for the survey. Therefore, 150 businesses (comprising manufacturing 24, service 70 and retail 56) were selected by means of stratified random sampling for the survey. Desktop research, involving telephoning respondents, was conducted.

\section{Study Design}

A quantitative approach was used to gather adequate and reliable field information. In terms of the quantitative approach, the rationale was to profile the market, identify their needs and quantify their demand for business services. The questionnaire designed for the survey was piloted using five businesses. Minor difficulties identified during the pilot resulted in the realignment of the questionnaire for the main survey. Interviews were conducted telephonically. The questionnaire designed was then used to capture interviewee responses. Respondents were business owners or senior decision-makers responsible for decisions relating to their company's use of business development services. The use of telephonic interviewing survey technique was based on the reason that it is the most effective and efficient way of gathering quantitative information.

\section{RESULTS}

The sectorial breakdown of respondents constituted manufacturing (16\%), service (45\%), retail (37\%) and other (2\%). The service sector had the largest number of respondents and ranged from security, mechanical to electrical businesses, with an average annual turnover of R1.5million (approximately 200000 USD) of the four categories, manufacturing had the most staff. However, the majority of respondents that expressed interest in future training belonged to both service and retail sectors.

The average age of respondent businesses was 11 years, with a significant number aged between $6-10$ years. The Business forms ranged from Sole Proprietor to Private Company Pty Ltd, with Close Corporations comprising the largest (46\%) of the legal structure of choice. With the second largest being Sole Proprietorship at $30 \%$ and then Partnerships at $15 \% .51 \%$ of the respondent businesses outsource some of their financial functions to bookkeepers, 9\% chartered Accountants, 29\% accountants and 11\% accounting officers, with the former representing the largest percentage. The majority of the businesses surveyed were owner(s) managed, with $65 \%$ comprising employee staff. Survey results also indicate that the majority of management's qualifications were between grade 12 and diplomas, with (66\%) at this level. The average number of employees per business was calculated at six, with $21 \%$ representing the owner manager. Therefore we can assume that the average business has approximately two people acting as owner/manger and 4 people as staff. This alerts one to the need for the owner manager to be highly multi-skilled.

The general trend is that the majority of respondents $(72 \%)$ had not used business services. Although some respondents blamed such decision on high price and bad service, this trend may emanate from either the respondents failure to recognize the importance of such business services or the capacity for such services exist within the respondents businesses. A reasonable few (32\%) had made use of business services; particularly the services of small consulting companies. Thirty four percent of respondents indicated that they were willing to use training services and undergo future relevant training. Seven percent of the respondents had utilized business management training while $6 \%$ received business plan training. Nine percent of the businesses indicated they had received product quality training. The majority beneficiary of the training was the manufacturing sector. The survey also showed market research and marketing is an important area of interest with $16 \%$ of the respondents indicating that 
they had received training in these areas. Other areas were: legal services 7\%, information technology 6\%, human resource management $7 \%$ and business insurance $6 \%$.

Another area of revelation from the survey was that few respondent businesses had utilized a different range of other services. The services ranged from product promotion to business evaluation and registrations. Respondents seem reluctant to pay for training with only (28\%) prepared to pay for such services. This should be seen in light of the fact that (80\%) of respondents spent nothing on business services.

Only $10 \%$ of the respondents identified different services their businesses may require but not currently met. The few services identified comprise business training, general consulting, financial management and export consultancy. Ninety percent of the survey respondents said they were satisfied with all the services currently received, and therefore, do not require any additional services. Of the 150 respondents, 138 businesses expressed no interest in receiving any additional services for business improvement, with only 12 respondents providing a contrary view. Services listed by some of the survey respondents are business evaluation, accounting and mentoring. It is also safe to say that businesses with proper structures, irrespective of size, are more likely to use the services of corporate and private concerns (bookkeepers, accountants, chartered accountants) instead of non-governmental organizations. On the issue of accessing finance, respondents seemed to be well aware of the dynamics involved. A total of $84 \%$ respondent businesses knew how to access finance. Only $16 \%$ respondents indicated that they still had to learn the intricacies of accessing finance and the need for additional finance. This is a common occurrence, as entrepreneurs only seem to worry about the procedures to access finance when they require such finances.

\section{DISCUSSION}

The results revealed that fairly established businesses do not seem to need or use business development services. This may be due to lack of awareness on the owner's part or perceived value for money. BDS are often called upon as a last resource, with heightened client expectations. It is often expected that consultants should be experts within very specialized areas. The lack of interest in BDS services would also suggest that most of the respondent businesses might have passed the difficult stage of business establishment and become more formalized and structured. conclusions.

Although training services did not rate extremely highly it is possible to draw some of the following

- $\quad$ Most of the businesses had limited staff capacity, about 6 people per business.

- $\quad$ Management capacity was also severely limited, about 2 people per business.

- $\quad$ Bookkeeping was outsourced.

- $\quad$ All management functions were limited to two managers, who normally had an education level of between grade 12 and a diploma.

- $\quad$ Most of these qualifications were often not linked to management studies.

- $\quad$ Given the cost of training against that of consultancy and the empowerment of the owner/manager it seems to have slightly more perceived value for money.

Further to this, information obtained through the research seems to support overlapping business training needs, as identified by survey conducted by the City of Cape Town in 2002.

However, what became clear was the fact that in looking for the support needs of a business, one should consider the relationship between the characteristics of the business in question against its degree of sophistication. Businesses surveyed may have common needs (see table 2); however, business support strategies required to address those needs may differ according to their characteristics and degree of sophistication. For example, a more sophisticated business may require specialized support compared to a less sophisticated business that may just need a generic support. Four general categories of business sophistication, with their typical characteristics can be identified. (See table 2). 
The question is how do you address the problem needs of a business that belongs to the growth-oriented segment? One has to understand the characteristic make-up of such business. From the survey, it became clear that the respondent businesses belonged to all the segments described above. However, majority, especially those that expressed business management training as their main support need, belonged to the segment - emerging and stable businesses. Sources from previous research indicate that about 40,500 businesses in Cape Town belonged to the emerging and stable segment of the market (table 3) (Neville M, Jaffray J, 2002).

Table 2: Scale of the business sophistication

\begin{tabular}{|l|l|l|}
\hline \multicolumn{1}{|c|}{$\begin{array}{c}\text { Degree of } \\
\text { Sophistication }\end{array}$} & \multicolumn{1}{|c|}{ Identifying characteristics } & Indicative Size \\
\hline $\begin{array}{l}\text { Survivalist / } \\
\text { Necessity } \\
\text { Entrepreneur }\end{array}$ & $\begin{array}{l}\text { These are the least sophisticated category of businesses. No market plans; } \\
\text { predominantly driven by skills/abilities of owner. Most such businesses are } \\
\text { informal. }\end{array}$ & Micro, Small \\
\hline Emerging / Stable & $\begin{array}{l}\text { Most common, and collectively the largest employer. Established in that they } \\
\text { have trading name, fixed place of business, identifiable debtors, creditors and } \\
\text { stock. Others are registered business entities. }\end{array}$ & $\begin{array}{l}\text { Micro, Medium } \\
\text { Mmall, }\end{array}$ \\
\hline Growth oriented & $\begin{array}{l}\text { Formal and established. Driven primarily by a desire/ability to take advantage } \\
\text { of an identified business opportunity. Emphasis is managing revenue growth. }\end{array}$ & $\begin{array}{l}\text { Small, Medium } \\
\text { and large }\end{array}$ \\
\hline Globally competitive & $\begin{array}{l}\text { Formal, established and structured, capable of competing for business on the } \\
\text { conscious basis of price, quality, flexibility or delivery. Activity is often } \\
\text { focused on the driving efficiency and managing costs. }\end{array}$ & $\begin{array}{l}\text { Small, } \\
\text { Medium, large }\end{array}$ \\
\hline
\end{tabular}

Source: City of Cape Town. Business Support Policy: Promoting the growth of existing and new businesses Draft, September 2002

Table 3: No. of businesses in Cape Town in each business sophistication category

\begin{tabular}{|c|c|c|}
\hline Category of business by sophistication index & Number & $\%$ of total \\
\hline Globally competitive & 1,350 & $2.3 \%$ \\
\hline Growth oriented & 3,150 & $5.4 \%$ \\
\hline Emerging / stable & 40,500 & $69.2 \%$ \\
\hline Survivalist/necessity entrepreneurs & 13,500 & $23,1 \%$ \\
\hline TOTAL & 58,500 & $100 \%$ \\
\hline
\end{tabular}

Source: City of Cape Town. Business Support Policy: Promoting the growth of existing and new businesses Draft, September 2002

The table indicates an interpretation of demand for supply of business support services for the various categories.

Globally competitive firms: market forces bring about a good alignment of demand and supply of business services. There is unmet demand for market opportunities (most - if not all - businesses seek to grow!), as well as for technology transfer and technology skills. Growth oriented businesses: market forces bring about a close alignment of demand and supply of business services delivered to growth oriented businesses, except in the areas of: market opportunities and technology skills (as with globally competitive firms); product/service development; marketing, sales and fulfillment; and human resource development and management where there are unmet needs.

Emerging and stable businesses have a strong demand for financial support, business management advice and skills, market opportunities and technical skills. Being generally based on the skills of the entrepreneur, demand for product development service is low. The level of business sophistication does not require advanced marketing and sales strategies, whilst in the area of human resource management there is something of an oversupply of service providers relative to demand. 
Survivalist firms and necessity entrepreneurs have a high, unmet demand for financial support and help with location of market opportunities; supply of other support services is low, but in line with demand. The demand and supply for most types of business support needs of more sophisticated businesses are roughly in balance. Those needs that are not addressed adequately strongly tend to be of an industry specific nature. Among the less sophisticated businesses, which constitute the majority from the survey context, there is unmet demand for Business skills training and access to market opportunities. These needs are generic, that is, similar regardless of industrial sector. A cross reference of the supply and demand table and the training services utilized from the survey demonstrates an overlap of needs. Theses were identified as finance and financial management, business management training, business plans, marketing and market research to a lesser extent.

BDS may be seen as a formal training process to many businesses. Kotey and Folker (2007) believe that small businesses prefer informal training and some of the factors that account for this preference are: owners perceive formal training as an affordable luxury involving not only course fees but also the cost of lost output while employees are off the job (Westhead and Storey, 1996); small businesses generally have a short term horizon because they face high levels of uncertainty. In contrast, benefits from training tend to be realized in the long term, which makes investment in training unattractive to small businesses; trained employees may be lost to other employers because of the relative lack of internal promotion opportunities.

\section{CONCLUSION AND RECOMMENDATIONS}

Critically any delivery of services must recognize the differing needs of survivalist, emerging, stable, growth-oriented and globally competitive businesses. Whilst the needs of these businesses vary with their degree of sophistication, so also do the channels through which these services are delivered. More sophisticated services are best delivered on a sector basis through industry bodies, whilst less sophisticated businesses generally require support through access to and the provision of 'generic business support services', which is not industry specific.

A reasonable few (32\%) had made use of business services; particularly the services of small consulting companies. The few services identified comprise business training, general consulting, financial management and export consultancy. Most of the businesses in this study were service businesses. Of the three categories of businesses, manufacturing had the most staff. However, the majority of respondents that expressed interest in future training belonged to both service and retail sectors.

Business development services mean a shift towards commercialization of business services. This phenomenon calls for a programme delivery approach based on client value strategy, professionalism and expertise in specialized or generalized field. Emerging and stable businesses have a strong demand for financial support, business management advice and skills, market opportunities and technical skills. The level of business sophistication does not require advanced marketing and sales. The new approach to business development services should be seen as a business in itself. This would entail identifying specific needs of business, considering its degree of sophistication and thereby providing services to meet those unmet needs.

\section{REFERENCES}

1. Caniëls, M.C.J., Romijn, H.A. \& De Ruijter, M. 2003. Can Business Development Services practitioners learn from theories on innovation and services marketing? Eindhoven Centre for Innovation Studies, Working Paper 03/07. Department of Technology Management: The Netherlands

2. City of Cape Town. 2002. Business Support Policy: Promoting the growth of existing and new businesses, Draft paper, September.

3. Clover, T.A and Darroch, M.A.G. 2005. Owners' perceptions of factors that constrain the survival and growth of small, medium and micro agribusinesses in Kwazulu-Natal, South Africa. Agrekon, 44 (2).

4. English, J. 2001. How to organize and operate a small business, $8^{\text {th }}$ Edition, Sydney: Allen \& Unwin. 
5. Folker, C \& Kotey, B. 2007. Employee training in SMEs: Effect of size and firm type- family and no family. Journal of Small Business Management, 45 (2): 214-238.

6. Gibson, A. 2000. The Development of Markets for Business Development Services: Where are we now and how to go further. (International Labour Organization)

7. Goldmark, L. 1996. Business Development Services: A Frame Work for Analysis. Working Paper Unidad de Microempresa, Departamento de Programas Sociales Desarrollo Sostenible, Banco Interamericano de Desarrollo.

8. International Finance Corporation IFC, World Bank Group.2006. Diagnostic Study on Access to Finance for Women Entrepreneurs in South Africa. Edited by Natalie Africa. November 2006.

9. Jackson, Paul Lehlohonolo Michael. 2004. Entrepreneurial Support in South Africa: A case study of a small enterprise support center in Johannesburg. Unpublished Masters Thesis. International Development Department. School of Public Policy. University of Birmingham.

10. Ladzani, W.M \& van Vuuren, J.J. 2002. Entrepreneurship training for emerging SMEs in South Africa, Journal of Small Business Management, 40 (2):154-161.

11. Mcvay M ET al.2000. Emerging Good Practices in Business Development Services. (International Labour Organization)

12. Mintzberg, H.1989. Mint berg on management: Inside our strange world of organizations. Collier MacMillan Canada, Inc, Canada.

13. Neville, M. \& Jaffray, J. 2002. Proposed Program for the Transformation of Economic Institutions.

14. National Small Business Act, Republic of South Africa, 2003.

15. Radipere, S and Scheers, L.V. 2005. Investigating whether a lack of marketing or managerial skills is the main cause of business failure in South Africa. SAJEMS NS 8 (4). School of Business Management, University of South Africa.

16. Westhead, P and Storey, D. 1996. Management Training and Small Firm Performance: Why the link is weak, International Small Business Journal, 14 (4): 13-25.

17. World Bank, 2000. Committee of Donor Agencies for Small Enterprise Development. Business Development Services for SMEs: Preliminary Guidelines for Donor-Funded Interventions. Summary of the report to the donor committee for small enterprise development. Washington DC.

18. $\quad$ http://www.safrica.info/doing business/trends/newbusiness/smallbusiness.htm 23/12/07 


\section{NOTES}

